\title{
Adivinhação, superstição e religião no último século da República (Cícero e Lucrécio)
}

\author{
MARIA DA GLORIA NOVAK \\ Departamento de Letras Clássicas e Vernáculas \\ Faculdade de Filosofia, Letras e Ciências Humanas \\ Universidade de São Paulo
}

\begin{abstract}
RESUMO: Confundem-se religião e superstição no último século da República e a religiāo é poderosa arma nas mãos dos poderosos. O homem se sente fraco e imagina forças sobrenaturais que o protejam, tendência que o estoicismo reforça e o epicurismo combate. Assim, adivinhação e epicurismo são absolutamente incompativeis. Lucrécio, materialista e coerente, clama contra todas as formas de superstição e contra o comportamento absoluto que dela deriva. Cicero (que tão veementemente critica a adivinhação) defende-a e defende também a religião oficial, porque sabe que só esta pode manter o homem livremente submisso ao Estado.
\end{abstract}

PALAVRAS-CHAVE: Adivinhação romana, Cícero, Lucrécio.

No último livro das suas Histórias, disse Polibio (c. 202-120) sobre a religião romana:

Parece-me que a particularidade mais importante, pela qual se marca a superioridade do Estado romano, reside nas idéias religiosas. E penso que Roma deve a sua coesão justamente ao que se censura nos outros povos, quero dizer à superstição. Esse aspecto é tão dramatizado aí e desempenha tal papel, tanto na vida particular como nos assuntos públicos, que nada poderia ser mais forte. Sem dúvida, muitos se admirarão disso mas, ao meu ver, os romanos ao fazê-lo pensaram na massa do povo. É verdade que, se se pudesse formar uma cidade de sábios, absolutamente não se imporia tal solução. Mas, visto que a massa é sempre instável, cheia de desejos culpáveis, de impulsos irracionais, de paixões violentas, o único meio de contê-la reside no medo ao mistério e nessa espécie de recurso ao drama. Creio, pois, que introduzindo no povo noções sobre os deuses e idéias de além-túmulo os antigos não agiram levianamente e ao acaso; a leviandade e 0 absurdo estão muito mais nos modernos que rejeitam isso tudo [56, 6-12].

Três séculos antes, Crítias (c. 460-403 a.C.), tirano de Atenas e adepto das doutrinas sofisticas, escrevera que os deuses são invenções do Estado para obrigar o homem 
a respeitar a lei (DK 88 B 25). E muito mais tarde, em 1734, Montesquieu (1689-1755), em brilhante e severa análise da religião romana, diz:

Vejo esta diferença entre os legisladores romanos e os dos outros povos: os primeiros fizeram a religião para o Estado e os outros o Estado para a religião. [...] Quando os legisladores romanos estabeleceram a religião, não pensaram nem na reforma dos costumes nem em fixar princípios de moral; não queriam incomodar gente que eles ainda não conheciam. Tiveram, pois, inicialmente apenas uma idéia geral, que consistia em inspirar, a um povo que não temia nada, o medo aos deuses, e em servir-se desse medo para conduzi-lo ao seu bel-prazer [s.d., p. 205-6].

Ora, no último século da República, a religião oficial, tendo embora os seus defensores, reduz-se praticamente à rotina dos cultos. Empenha-se também o Senado em conservar-lhe a autoridade contra a infiltração de crenças e práticas estrangeiras. Entretanto, quase nada pode fazer, pois a religião muda com a política e segundo os interesses das suas figuras mais importantes. A verdade é que os políticos usam "politicamente" a religião e os prodigios.

O supersticioso (?) Mário faz-se acompanhar de uma vidente síria. César simultaneamente parece crer nos auspícios e caçoar deles ou interpretá-los ao seu modo ${ }^{1}$. Cético, não o dissimula e utiliza o medo supersticioso do próximo. Não dá nenhuma importância aos presságios quando estes contrariam os seus planos (Madaule, 1961, p. 11).

Como afirma Dumézil $(1974$, p. 543), entre as superstições orientais e a religião que os políticos manobram, encontram-se a indiferença e o ceticismo dos jovens e a lucidez dos intelectuais: de Varrão, de Cícero, de Lucrécio, por exemplo.

$O$ poeta escreve quase sete mil e quinhentos versos para demonstrar que tudo no mundo resulta do movimento dos átomos, que nada, jamais, foi criado pela vontade divina, e que os deuses são alheios ao nosso mundo e à nossa vida.

Varrão, apoiando-se na tese do pontífice Múcio Cévola ${ }^{2}$ (que distingue os deuses introduzidos pelos poetas dos introduzidos ou pelos filósofos ou pelos chefes políticos), analisa e define uma teologia tripartida: 1. teologia mítica, que convém ao teatro; 2. teologia física, que convém ao mundo; 3 . teologia civil, que convém à cidade: os cidadãos, sobretudo os sacerdotes, devem conhecer os deuses aos quais devem culto públi$\mathrm{co}$, e as cerimônias e os sacrificios a que são obrigados.

Cícero, defensor da grandeza da Vrbs, político acima de tudo, advogado da causa romana, defende a religião oficial. Estuda-a nas suas relações com o comportamento do povo e com a estabilidade do Estado. Escreve sobre religião e filosofia, não como simples estudioso ou tradutor de obras filosóficas, segundo muitas vezes se diz, mas como homem público por demais preocupado com o comportamento dos seus concidadãos e os destinos da pátria. Em 54 e 52, De Republica e De legibus ${ }^{3}$, mais propriamente considerados como tratados políticos, aos quais, porém, não falta inquietação filosófica e religiosa; alguns anos mais tarde (em 45 e 44), Academicorum reliquiae, 
De finibus bonorum et malorum, Tusculanae disputationes, De natura Deorum, De diuinatione, De fato; e, ainda, Cato Maior, De amicitia, De officiis.

Desses diálogos, o De natura Deorum, o De diuinatione e também o De legibus constituem manancial riquíssimo para o estudo da adivinhação entre os romanos.

Entretanto, idéias pouco mais ou menos semelhantes às de Polibio (e Montesquieu...) encontram-se em vários passos dos seus escritos. Por exemplo, no De haruspicum responsis $(9,19)$, discurso pronunciado em 56 , declara enfaticamente que é pela piedade e pela religião que os romanos superam os outros povos. Igual afirmação põe na boca do estóico Lucilio Balbo, no De natura Deorum (II, 3, 8). No De diuinatione (II, 35, 75), embora atribua a origem do direito augural à crença na adivinhação, atribui-lhe a manutenção à causa da República. E no De legibus (II, 13,32) apresenta Ático pondo em dúvida o valor da adivinhação: afirma este que, enquanto para Ápio Cláudio os auspicios parecem poder como que adivinhar, segundo Marcelo foram criados para a utilidade da República.

Ora, Cícero defende a necessidade de uma consideração racional dos fenômenos (De diu., II, 11, 27). No De natura Deorum (III, 2, 5-3, 7), pela boca do acadêmico e pontífice Cota, afirma a sua crença na existência dos deuses, crença fundada na autoridade dos antepassados: mas quer uma prova dessa existência e quer a razão da religião - ratio religionis $(2,6)$. Aliás, distingue religião e superstição (II, 28, 71-2). No De officiis (III, 29, 104), afirma que a cólera dos deuses não existe. Repugna a superstição, que pode chegar a ser um atraso de vida (De leg., II, 18, 45) e lamenta que, espalhada entre as nações, tenha oprimido o espírito e dominado a fraqueza de quase todos os homens (De diu., II, 72, 148): radicalmente contra todas as formas de superstição $\mathrm{e}$ sinais que de todos os lados pressionam o homem e lhe impedem a paz do espírito, menciona-os como se numa torrente: profecias, avisos, sacrificios sangrentos, vôo dos pássaros, arte dos caldeus, aruspicina, relâmpagos, trovões, raios, prodigios, interpretação de sonhos. Outras vezes ridiculariza a superstição ou chega a negar-lhe a existência no coração humano, afirmando que não há uma só velhinha que acredite nessas coisas... (Tusc. disp., I, 21, 48; De diu., II, 15, 36). Diz que aceita as histórias dos poetas como se deve aceitá-las e ridiculariza os que acreditam que Numa conversava com Egéria ou que a mitra fora imposta a Tarquínio por uma águia (De leg., I, 1, 4).

São, entretanto, proverbiais as oscilações de Cícero. E noutro nível reconhece o valor e mérito da lenda e, defendendo a religião e a piedade, defende a veracidade das profecias (De har resp., 9, 18-9); e as leis religiosas por ele expressas no De legibus (II, 8, 19 seq.) não se afastam muito nem das leis de Numa nem das tradições. Diz, em suma, que é preciso velar pelas instituições dos antepassados. E é invocando o conhecimento da religião aliada à natureza que quer descartar a superstição, e faz uma profissão de fé em algo superior e eterno, que se deve admirar e cuja existência a beleza do mundo e a ordem dos seres celestes obrigam a confessar. (Oposição ao De rerum natura? Em todo caso, posição estóica.) 
É dificil esquematizar a religião romana, ao mesmo tempo conservadora e estática, fiel aos pormenores do rito, severa quanto ao desempenho do ofício, e ao mesmo tempo assimiladora e dinâmica, nacionalizando religiões e deuses. Como diz Montesquieu,

[...] os romanos confundiam sabiamente as divindades estrangeiras com as suas: se encontravam nas suas conquistas um deus que tivesse relação com algum dos que se adoravam em Roma, eles o adotavam, por assim dizer, dando-lhe o nome da divindade romana e the concediam [...] o direito de cidadania em Roma [s.d., p. 219].

Entretanto, pode-se, até certo ponto, acompanhá-la, pois a religião romana consiste basicamente em sacra e auspicia, segundo afirma Cota no De natura Deorum (III, 2, 5). Os primeiros, cuja instituição é tradicionalmente atribuída a Numa Pompilio, são as cerimônias do culto e o próprio culto ${ }^{4}$. Auspicium é, a rigor, o fato de captar o sinal fornecido pela observação do vôo das aves; e, lato sensu, qualquer espécie de presságio (Ernout e Meillet, 1967, p. 58, col. 2). Acrescentam-se depois à religião oficial a aruspicina e os livros sibilinos (De nat. Deo., III, 2, 5).

Há originalmente no exercício da religião romana cinco sacerdotes, um dos quais, o Pontifex, acrescenta o imperium ao direito de auspícios ${ }^{5}$. Mais tarde, são mais numerosos e no De legibus (II, 8, 20-9, 21) Cícero precisa-lhes as funções e as classes. Destas, a primeira preside às cerimônias e aos ritos. A segunda interpreta as palavras dos adivinhos (fatidici) e dos profetas (uates), reconhecidos pelo Senado e pelo povo. (É interessante assinalar que os adivinhos e profetas nem sempre foram reconhecidos pelo Senado.) À terceira e mais importante pertencem os intérpretes de Júpiter O.M., os áugures. $\mathrm{O}$ seu símbolo é o lituus, bastão ligeiramente curvo no meio e arredondado numa das extremidades, semelhantes a uma trombeta, objeto do qual tem o nome. Tềm eles o encargo dos auspícios (De diu., I, 15, 25), ou seja, pertence-lhes precipuamente conhecer a vontade dos deuses. $\mathrm{O}$ romano quer, antes e acima de tudo, a aprovação divina, e assim se explica a repetição do sacrificio até o resultado favorável (usque ad litationem).

Assim é que Rômulo, segundo se diz, fundara a cidade após consultar os auspícios - e isso teria sido o início da República —, e teria escolhido áugures, um de cada tribo, que o auxiliassem nessa consulta em todas as decisões que viesse a tomar.

Nam et ipse, quod principium Reipublicae fuit, Vrbem condidit auspicato, et omnibus publicis rebus instituendis, qui sibi essent in auspiciis, ex singulis tribubus singulos cooptauit augures [De Rep., II, 9].

Como a idéia é viver em paz com os deuses e jamais, portanto, contrariá-los, é indispensável conhecer-lhes a vontade, e as mais antigas formas de consulta visam apenas a saber se os deuses estão ou não de acordo com os planos de ação. Posteriormente, com a influência exercida pela aruspicina e pelos livros sibilinos, o desejo de 
conhecer o futuro sobrepuja a simples consulta augural, e Cícero escreve no De legibus (II, 8,20$)$ que, por meio de sinais e auspícios, os áugures conhecerão os fatos vindouros.

Desde o início, diz o Orador, a eles cabe conservar a ciência e transmiti-la aos sucessores; dar a conhecer os auspícios e exigir obediência; prever e evitar as iras divinas. $\mathrm{O}$ que quer que $\mathrm{o}$ áugure defina como injusto, nefasto, vicioso ou funesto não será nem ratificado nem realizado (De leg., II, 8, 20; III, 4, 11).

O defensor da $V r b s$, tanto quanto Políbio desconfiado da instabilidade da massa ${ }^{6}$, enaltece o valor dos sacerdotes oficiais: dos que, encarregados de presidir às solenidades sacras, aplacam os deuses; dos que interpretam as predições dos uates; e talvez, principalmente, dos áugures, intérpretes e ministros de Júpiter. Diz ele:

Maximum autem et praestantissimum in republica ius est augurum cum auctoritate coniunctum [De leg., II, 12, 31; III, 19, 43].

O maior e mais poderoso direito da República é o dos áugures, intimamente unido à autoridade.

É o direito que pode dissolver ou anular comícios e assembléias instituidos pelas mais altas patentes civis e militares; decretar a abdicação de cônsules; abolir leis ilegalmente propostas, como fez Filipo, cônsul e áugure, que aboliu as leis Lívias.

Essa estrutura pontifical é, segundo Cícero, a garantia da República, visto que obriga sempre o povo a precisar do conselho e autoridade dos "mais dignos", os optimates, que o Orador define no discurso a favor de Séstio (14, 96 seq.).

A verdade é que, de fato, religião e moral garantem a estabilidade do Estado. Associam-se desde sempre magistratura e sacerdócio e, embora assistidos por membros do Colégio dos áugures, todos os magistrados têm direito de tomar os auspícios, como se lê no De legibus (III, 3, 20). A autoridade do Colégio permanece, mesmo após o esmorecimento da crença (Boyancé, 1963, p. 101). E mais, o magistrado sacerdote é a lei:

Magistratum legem esse loquentem, legem cutem mutum magistratum [ibid. 1, 2].

O magistrado é a lei falando, e a lei é o magistrado em silêncio.

Realmente, como assinala Coulanges (1969, p. 211-2), embora não concorde com a análise de Montesquieu, o magistrado representa a cidade, que é uma associação religiosa ao menos tanto quanto política; e tem nas mãos os auspícios, os ritos, a oração, a proteção dos deuses. Um cônsul é mais que um homem: é intermediário entre o homem e a divindade.

A própria expressão auctoritas, da mesma raiz de augur, significa também "o fato de possuir a eficiência necessária para empreender algo" ". E todo empreendimento é determinado pela religião: as festas, a agricultura, as decisões políticas; e a maior preocupação dos magistrados e sacerdotes é a pax Deorum: a cidade, sem a summa placatio dos deuses imortais, diz Cota no De natura Deorum (III, 2, 5), não poderia ser tão grande como é. 
O sentido do termo augur (raiz de augeo, "aumentar") poderia também ser, na origem, o de fortalecimento concedido pelos deuses a uma empresa, donde, presságio favorável; ou designaria aquele que dá o fortalecimento, donde, aquele que dá presságios favoráveis ${ }^{8}$. Como assinala Bayet (s.d., p. 103), nada tem a ver com as aves do presságio: significa, mais, o poder de acréscimo, a valorização quer do presságio, que pela virtude do rito se torna determinado, quer da vontade divina, reconhecida e enunciada pelo áugure. Appuhn (1937, n. 5), citando Sérvio, distingue auguria e auspicia: o primeiro termo designaria a observação do caso ou objeto que se apresentasse espontaneamente, ao passo que os auspicia (de auis + spicio) seriam provocados.

Dumézil (1969, p. 79 seq.), apoiando-se no védico ójas, "força física, reserva de força, pleno de força", em que pese o perigo de tais comparações, precisa a significação do termo, embora em latim essa força não se ligue particularmente à força fisica do guerreiro mas aos interesses humanos naturais (fecundidade, por exemplo), ou sociais (políticos, religiosos e guerreiros), como prova o texto ciceroniano (De leg., II, 8, 21).

Em última análise, é função do áugure descobrir se os deuses concederão a força, ou seja, condições de sucesso às plantas, à batalha e à decisão política; à cidade e ao campo, ao templo. Como destaca Dumézil, a ciência dos áugures deve ter valor de consulta, não de influência, embora, a rigor, se possa perceber alguma ação dos áugures sobre os fatos. No De legibus (II, 8, 21), por exemplo, há claros reflexos da força dos áugures sobre as intenções dos deuses. Encontrar-se-ia talvez aí a brecha que permitirá mais tarde o florescimento e domínio da magia oriental em Roma.

É verdade que, no De diuinatione, afirma Quinto, o estóico interlocutor de Cícero:

Etenim dirae, sicut cetera auspicia, ut omina, ut signa, non causas afferunt cur quid eueniat, sed nuntiant uentura, nisi prouideris [I 16, 29-30].

As ameaças, assim como os outros auspícios, avisos, sinais, não produzem as causas de que algo aconteça mas anunciam o que ocorrerá se não nos prevenirmos.

Ora, ainda quando possa não haver influência sobre os fatos, certamente haverá sobre os consulentes: estes devem, se os auspícios são desfavoráveis, abster-se da ação tencionada, pois não obterão o sucesso que desejam.

Seja como for, primitivamente o áugure possuiria talvez o "pleno de força" e o comunicaria aos fatos, o que justifica a aproximação entre rex e $a u g u r^{9}$ sendo Rômulo tradicionalmente detentor de extraordinário poder augural. Mais tarde, intensifica-se novamente a idéia da força do áugure ${ }^{10}$. Primeiro porque permanecem os "resíduos mágicos" do presságio, o respeito às práticas religiosas, a crença popular. Segundo porque, talvez, em vista do individualismo e ambição dos conquistadores, o poder adquirido precisa estribar-se em algo superior à sua própria força. Estreita-se a relação entre imperator e augur, desenvolve-se a noção de felicitas, característica do individuo ajudado pela vontade divina e pela Fortuna, caracteristica do chefe que sobrepuja 
todos os outros, como bem assinala Cícero (De imp. Cn. Pomp., 16, 47-8). E os generais invocam a arte augural como fator de vitória ${ }^{11}$.

Ora, a força do presságio ligada ao poder (imperium) é insuperável. E a relação intima entre poder temporal e poder sacerdotal está inequivocamente documentada nas moedas romanas.

Por outro lado, a felicitas, em última análise, eleva um homem - como Sula e Pompeu, César e Augusto - acima dos homens e resulta na divindade do último, para a qual terá, sem dúvida, contribuído o evemerismo. São numerosas nos escritos de Cícero as ocorrências, é verdade que nem sempre favoráveis, da idéia de Evêmero. No Pro Sestio $(68,143)$ e no De Republica (VI, 13), por exemplo, promete a imortalidade ou, melhor, atribui essência divina aos bons governantes, embora mais tarde, em se tratando de Antônio, repugne a idéia de pôr um mortal entre os imortais.

Inversamente, com o passar do tempo, os sacerdotes acumulam de tal forma funções civis que acabam por afastar-se do sentido propriamente religioso, como não pode deixar de reconhecer Cícero (De leg., II, 21, 52).

Evidentemente conhece a classe dominante de Roma os usos oportunistas que se fazem dos auspícios e das profecias mas conhece também as suas vantagens reais e, pois, a sua necessidade ${ }^{12}$. E talvez não convenha negar a adivinhação.

É verdade que no II livro do De diuinatione $(49,101$ seq.), escrito após os idos de março de 44, Cícero critica o raciocínio de Quinto e reduz a importância dos livros sibilinos, das profecias de Cassandra, a que chama fabulae, e dos oráculos de Apolo, de fato a esse tempo mudo, como aliás é obrigado a reconhecer Quinto $(I, 19,37-8)$. Cícero invoca o testemunho de Demóstenes para desacreditar a Pítia, que, favorável a Filipe, segundo o ateniense, "filipizava"13; e acusa de corrupção o oráculo de Delfos. Reduz também a importância dos sonhos e nega-lhes origem divina.

Segundo ele, deve-se confessar que nada é expresso pelo deus através de sonhos. E considera a sua obscuridade no minimo incompativel com a majestade divina. $\mathbf{O}$ Orador relata sonhos interessantíssimos e suas respectivas - e dúbias - interpretações. Mesmo sonhos claros como o de Alexandre com o dragão, o seu próprio e o de Quinto, antes mencionados por este (De diu., I, 28, 58), podem ser racionalmente explicados. E apresenta três hipóteses de aceitação dos sonhos como sinais do futuro: 1. mensagem divina; 2. relação com objetos reais pela simpatia universal, e 3. possibilidade de interpretação por meio de uma ciência oriunda da observação de inúmeros sonhos: e uma a uma as derruba, concluindo que a adivinhação pelos sonhos é inaceitável (II, 72, 148). É também no De diuinatione (II, 9, 22) que refere a inutilidade da adivinhação.

No De legibus, entretanto, escrito oito ou dez anos antes, defende-a. Liga a parte referente às aves e a outros sinais à ciência dos áugures. Se há deuses, diz, se o mundo é regido pela mente divina, se se interessam os deuses pelo gênero humano e podem mostrar-nos sinais de fatos futuros, como negar a adivinhação? Além disso, inúmeros seriam os exemplos de ocorrências preditas pelos áugures; e não seriam ilustres tantos profetas do passado, e Rômulo não teria tomado os auspícios antes de fundar a cidade 
se não houvesse verdade na arte da adivinhação (Diuinationem esse sentio, II, 13, 32-3). E no De haruspicum responsis, anterior ao De legibus, ao enaltecer a sabedoria e a prudência dos antepassados (e assumir posição contra os epicuristas), dá exemplos de profecias "inequivocas" $(9,18)$.

De fato, há desde os ancestrais uma ciência e arte augural, pertinentes às vezes aos interesses da República e a planos de ação. Políticos e militares a ela recorrem, guiados pelos áugures (os verdadeiros detentores do poder). Não sem razão se representa nas moedas o lituus, bastão símbolo da dignidade augural, com o qual teria Rômulo demarcado os limites da cidade (De diu., I,17,30); não sem razão se lhe atribui a tomada dos auspícios antes de fundá-la. Não se dá um só passo religioso ou político em Roma sem a tomada dos auspícios (De diu., I,43,95).

Tito Lívio enfatiza o poder do áugure no episódio de Ato Návio (I, 36, 3-4), episódio que se não resiste a uma exegese cuidadosa (primeiro porque os áugures romanos, ao contrário dos arúspices etruscos, às vezes chamados prodigiatores ou fulguratores, não são mágicos ou milagreiros; e segundo porque Tarquínio, sendo etrusco, não duvidaria da arte augural [Bloch, 1965, p.47]) mostra ao menos o poder e importância dessa arte, como pretende Quinto no De diuinatione (I, 17, 31-2). Delimite-se o templum; formule-se a prece; observem-se o canto e o vôo das aves, ou o relâmpago ou o trovão; os deuses sabem como desejam manifestar-se e os áugures lhes entendem as mensagens.

Aliás, como se lê em Plínio (N.H., 28, 17), a ação dos presságios está em nosso poder, e o seu valor depende do modo como se interpretam ${ }^{14}$. Talvez se lembrasse dos doze abutres que haveriam significado para Rômulo a supremacia diante do irmão, ou dos que teriam aparecido ao novo Rômulo no seu primeiro consulado (Suet., D. Aug., $95,2)$. Enfim, o que importa ao sucesso da adivinhação é o modo como é recebida pelo consulente: sem crença, consulta ritual e sacrificio não têm valor. Cícero, lembrando Lucrécio, destaca esse ponto - Ad diuos aduento caste (De leg., II, 8, 19).

A adivinhação deveria, pois, estar ligada à noção de deuses, e vários são os modos de conhecimento da vontade divina ou dos fatos ruturos em Roma; e se podem classificar em duas espécies: artificiais e naturais, como bem o explica, no De diuinatione, Cícero através de Quinto:

Duo sunt enim diuinandi genera, quorum alterum artis est, alterum naturae [I, $6,11] ;[. .$.$] duo genera diuinationum [. .$.$] unum quod particeps esset artis, alte-$ rum quod arte careret $[18,34]$.

As formas naturais de adivinhação, as chamadas formas não científicas, afastamse das religiosas, isto é, embora revelem ( $(\mathrm{sic})$ a vontade divina, não pertencem propriamente à religião por não dependerem de consulta mas unicamente da disposição psicológica do receptor. Compreendem os oráculos dos sonhos e do delírio - somnii et furoris oracula (De diu., I, 32, 70; II 48, 100)-, isto é, dos oráculos, embora não todos: 
não os resultantes das sortes mas somente os que resultam de um instinto ou sopro divino, como os oráculos de Apolo a Creso e a outros, colecionados pelo estóico Crisipo, segundo lembra Quinto (De diu., I, 19, 37). Acrescentem-se os omina (avisos fortuitos ou fatos que se carregam de significação), tipo especial de aviso. Termo de origem obscura, designaria stricto sensu palavras reveladoras do futuro - uoces ex occulto (De diu., I, 45, 101) -, mas lato sensu quaisquer manifestações fortuitas, ou seja, qualquer espécie de aviso.

A crença nesses avisos parece profundamente arraigada na mentalidade romana. Conta-se, por exemplo, que Rômulo matara o irmão porque este saltara sobre os muros da cidade: fato profético: igual destino teria qualquer que ousasse transpor os limites de Roma.

Os avisos, embora possam talvez na sua origem não ser considerados como dependendo dos deuses e embora sejam sujeitos a errônea ou dúbia interpretação, encaixar-se-iam perfeitamente no destino dos homens e das coisas, segundo se pensava e se depreende dos exemplos de Virgílio, cuja obra máxima, a Eneida, é também fonte excelente para o estudo da antiga religião e das antigas crenças, plenas de oráculos e de presságios, que muitas vezes desafiam a interpretação humana ${ }^{15}$. Parece-me que bastariam apenas dois exemplos. Primeiro, o vôo da Fúria transformada em pássaro, que Júpiter envia a Juturna para que ela abandone Turno, e o combate (XII, 853). O Poeta diz textualmente omen: entenda-se o termo no seu sentido lato de "aviso". E também a profecia de Celeno, de que a fome os levaria ao ponto de devorar, durante a refeição, até as próprias mesas (III, 255-8; VII, 122).

Valério Máximo (séc. I d.C.), freqüentemente valendo-se de textos ciceronianos, relata nos seus Fatos e palavras memoráveis alguns avisos e sonhos interessantes ${ }^{16}$.

Pensava-se que estes, os sonhos, poderiam ser também a princípio independentes dos deuses, apesar de sua força profética ${ }^{17}$. Ainda uma vez é Virgílio quem nos dá extraordinários exemplos de sonhos proféticos, nos quais, porém, se deveria sentir (como parece querer o Poeta) nitida interferência divina: vejam-se os sonhos de Enéias com Heitor (II, 270), com os deuses Penates (III, 148), com o deus do Tibre (VIII, 28), a orientá-lo no cumprimento do destino. Cícero, porém, não acredita em sonhos proféticos (De diu., II, 72, 148); nem Lucrécio, evidentemente, que os estuda como fato natural (IV, 962 seq.).

$\mathbf{O}$ delírio seria, a rigor, a posse e inspiração pelo deus e necessidade de dizer. Bom exemplo é, na Eneida, o de Heleno (III, 369 seq.), que, após sacrificar ao deus e preparar-se para a inspiração, é realmente, segundo o Poeta, inspirado por Apolo e revela a Enéias alguns fatos que devem orientá-lo na longa viagem.

Mas o maior exemplo em Roma será talvez o dos livros sibilinos, versos oraculares entregues a intérpretes, sob a guarda do Senado. A sua consulta e interpretação nos momentos dificeis da República é seguida de sacrificios que renovam a confiança nos deuses e visam tranqüilizar o povo (De diu., II, 54,112). Esses versos teriam sido escritos pela Sibila de Cumas em delírio. A princípio não se menciona o deus inspirador ${ }^{18}$; 
só mais tarde, Apolo, a coincidir com a presença cada vez mais acentuada do deus na literatura e na crença - o que desperta reações como a de Lucrécio (I, 730; V, 112) -, para culminar alfim no templo do Palatino, dedicado em 28 a.C.

Cícero discorda de que fosse obra de alguém em delírio; segundo ele, o poema demonstra claramente que é mais um trabalho de arte que de excitação, visto ser perfeitamente bem estruturado (De diu., II, 54, 111). Como pensa Bloch (1965, p.49), a personagem autora dos livros sibilinos poderia ser criação tardia de escritores gregos e latinos. Os romanos quiseram sempre - embora nem sempre o fizessem - afastar de sua religião os etruscos: Tarquinio o Antigo teria duvidado da arte de Ato Návio; o Soberbo (ou talvez o próprio Antigo) se teria inicialmente recusado a comprar os livros de Sibila; e o templo do Capitólio, a Júpiter O.M., Juno e Minerva, prometido por Tarquínio o Antigo e construído pelo Soberbo nos fins do século VI, não só - de acordo com a tradição romana - teria sido consagrado por um cônsul romano, como, ainda, os etruscos teriam sido expulsos de Roma no mesmo ano da consagração.

Antes de passar às formas artificiais de adivinhação, parece-me interessante lembrar, ainda que em poucas palavras, a influência da filosofia, a que não é estranha a $V r b s$, que sofrera desde cedo influências pitagóricas. Mais tarde, sobretudo a partir do século II a.C., conheceu as filosofias da natureza, estoicismo e epicurismo, que dominam, afinal, o século de Cícero e Lucrécio.

Ao estoicismo, que se irradiara do círculo dos Cipiões, a que pertencia Políbio, prende-se intimamente a adivinhação.

O epicurismo, doutrina materialista que se espalhara pela Península, é representado principalmente por Tito Lucrécio (c. 99 - c.55), que combate toda e qualquer forma de superstição: poderes atribuídos aos deuses $(\mathrm{V}, 1194)$, profecias, adivinhações e interpretações falaciosas (I, 107-9), sacrificios sangrentos (I, 101; II, 352-66; V, 1201), lendas e crenças aberrantes (II, 645), contra os quais, mais tarde, se insurge também Cícero, inimigo figadal do epicurismo.

Para os epicuristas como para os estóicos, os deuses existem e sua existência é uma noção natural da alma, ou seja, a noção de Deus está impressa no homem. Entretanto, para uns e outros é diferente essa impressão no homem.

Segundo o epicurismo, os deuses existem porque os vemos (De rer. nat., V, 116982), embora nada tenham a ver com os mundos e os homens; e são inúteis oferendas e sacrificios.

Segundo o estoicismo, quatro são as causas pelas quais se explica a formação na alma humana da idéia de Deus, como afirma Lucilio Balbo, o expositor da doutrina estóica no ciceroniano De natura Deorum (II, 5, 13-5): 1. conhecimento do futuro; 2 . visão da terra e dos bens que ela nos dá; 3. medo inspirado pela fúria dos elementos; 4 . movimento dos astros. Os deuses, ao contrário do que diz o epicurismo, exercem ação reguladora no mundo e velam sobre a humanidade (ibid., 2,6).

Interessante é a assertiva de que a adivinhação é prova de que os deuses existem; e segundo Quinto recusar-se a crer nos presságios é recusar-se a crer na existência dos 
deuses (De diu., I, 46, 104). Esta assertiva, como assinala Cícero no mesmo diálogo, está no cerne da filosofia estóica:

si diuinatio sit, Di sint et si Di sint sit diuinatio [I, 6, 10]; sunt autem Di; significant ergo [...] est igitur diuinatio [I, 38, 83].

se há adivinhação há deuses e se há deuses há adivinhação; ora, há Deuses, logo, dão sinais [...] portanto, existe a adivinhação.

Todo esse esquema, porém, Cícero (De diu., II, 49, 101 seq.) e mais tarde Luciano de Samósata (II d.C.) ridicularizam.

Convém lembrar que, segundo o estoicismo, a adivinhação é uma ciência. É possível, dizem os estóicos, prever o futuro porque a vida sempre volta ao que foi. Esta idéia - a teoria do eterno retorno - , que se tem geralmente por estóica e se atribui a Crisipo da Cilícia (c. 280-204), teria tido o seu berço na Babilônia. Fora também conhecida de Heráclito de Éfeso (c. 540-470) e dos primeiros pitagóricos, que a relacionariam com a idéia de metempsicose. Crisipo da Cilícia definiria a adivinhação como a faculdade de conhecer, ver e explicar sinais anunciados pelos Deuses ao homens (De diu., II, 63, 130).

Pois bem. As formas artificiais são as chamadas formas científicas de adivinhação, defendidas pelos estóicos. A sua arte ora se contém nos livros de regras, como os livros etruscos e os livros rituais romanos, ora consiste numa interpretação improvisada de um prodigio (De diu., I, 33, 72-3). A elas pertencem a arte dos áugures em primeiro lugar, e as sortes, a anuspicina e a astrologia.

Esta, que da Caldéia começara a difundir-se pelo Mediterrâneo a partir dos inícios do século II a.C., apóia-se em conhecimentos científicos tais como a regularidade do movimento dos corpos celestes e, embora se difundisse na Vrbs não chega a ser assimilada à religião romana. Tem seu grande defensor no estóico Posidônio de Apaméia (c. 135-c. 51), discípulo de Panécio de Rodes (c. 180-c. 110) e seu sucessor na Escola de Rodes. Posidônio, ao contrário do mestre, que defende a liberdade do homem contra o domínio da necessidade, insiste na concepção cosmológica oriental e na interação dos fatos, reduzindo tudo à unidade, através do conceito de simpatia: segundo ele, todas as partes do cosmos relacionam-se e influenciam-se umas às outras, o que permite a astrologia e a adivinhação ${ }^{19}$.

Ora, no século I a.C. a insegurança provocada pelas guerras civis e pela fraqueza do Senado, a imoralidade e a incerteza do futuro levam o homem a procurar em si mesmo a sua força. No estoicismo, como no platonismo, são os astros responsáveis pelo destino do homem, e este, parcela do cosmos, pode conseguir a imortalidade. Nada mais fascinante. Cícero pensa na $V r b s$, e essa imortalidade astral, oferece-a aos que tenham defendido, ajudado e enriquecido a pátria ( $D e$ Rep., VI, 13), embora no De diuinatione (II, 42, 87 seq.) ccmbata a astrologia com os argumentos de Panécio. Retoma no De fato a crítica, negando não só a influência dos astros $(4,8)$ mas também a simpatia universal $(3,5)$ e o destino $(5,9)$, sem o qual a explicação de tudo se reporta à 
natureza e ao acaso $(3,6)$. Na verdade, Cícero é mais contra os astrólogos que propriamente contra a astrologia e leva ao paroxismo a luta contra as superstições importadas e contra os mentores das novas crenças: se estas respondem aos anseios mais intimos do povo, aqueles enriquecem à custa da credulidade alheia. Apesar disso, a adivinhação pela astrologia apoiada pelos estóicos e pela teoria do eterno retorno, vai ao encontro do poder e cria forças. Os seus únicos e verdadeiros opositores são os epicuristas. Mais tarde os imperadores perseguem os astrólogos, se não para proteger o povo, certamente para proteger-se, visto que os consultavam mas temiam que certas predições se tomassem públicas.

A aruspicina, de origem etrusca, muito cedo é introduzida em Roma, conservando porém, durante muito tempo, seu caráter estrangeiro. Não alcança jamais o prestígio dos auspícios, e seus sacerdotes não alcançam jamais a honra dos áugures. Se é verdade que alguns deles gozaram do favor de governantes como Sula e César, é só em 47 d.C., sob Cláudio, que se cria enfim o Colégio dos arúspices, num momento em que a sua ciência é encarada como a mais antiga da Itália, em oposição às mais recentes importações ${ }^{20}$.

De uma raiz haru-har-, que significaria intestino, (h)aruspicina deriva de (h)aruspex,icis, "o que examina as entranhas das vitimas"21. Nesse exame e conseqüente interpretação consiste basicamente a sua arte. Acredita-se, então, que a consagração da vítima acarreta uma projeção do mundo em suas entranhas, que podem assim dar as indicações que os sacerdotes procuram. Aos arúspices cabe interpretar os prodigios e monstruosidades, como afirma Cícero no De legibus (II, 9, 21): ou seja, interpretar os presságios revelados por fenômenos estranhos ou contrários às leis naturais, que o Orador define através de Quinto no De diuinatione $(\mathrm{I}, 42,93)$ e que também no De diuinatione ridiculariza (II,28,61-2).

As sortes se processam mediante pedrinhas ou tabuinhas ou mesmo lâminas de metal ou varetas em que se inscrevem ou palavras (nomes próprios ou outras), ou letras, ou mesmo frases ou versos. Numa das formas de consulta, misturam-se; e um garoto, apanhando-as uma a uma, entrega-as a um adivinho que lhes interpreta a mensagem divina. Cícero põe em dúvida o valor das sortes e escreve:

Quid igitur in his potest esse certi quae, Fortunae monitu, pueri manu miscentur atque ducuntur? [De diu, II, 41, 86].

Que pode haver de certo nestes objetos que, por inspiração da Fortuna, são misturados e tirados pela mão de um garoto?

A seguir lamenta que os deuses, se é que tudo podem, como dizem os estóicos, não os impeçam de crer em todas as superstições.

As sortes, porém, são processo de adivinhação antiqüíssimo, e também antiquíssima, como bem o indica o epíteto Primigenia, é a deusa Fortuna (mesma raiz de sors): o seu culto, disseminado pela península central - entre latinos, sabinos, umbros e etruscos - remontaria a Sérvio Túlio, o penúltimo rei de Roma ${ }^{22}$. 
Cícero compara-as a jogos como os de dados, em que não valem a razão e o bom-senso mas apenas o acaso (De diu., $\Pi, 41,85$ ). O que é interessante porque, justamente, segundo os crédulos ou para os antigos, como assinala Coulanges (1965, p.213), a sorte não é o acaso mas a revelação da vontade divina.

Essas as principais formas de adivinhação, e as mais antigas, entre os romanos.

Ora, embora se costume distingui-las principalmente entre naturais e artificiais, parece-me que se enquadram em dois niveis absolutamente distintos, e a arte augural e a tomada dos auspícios ocupam o primeiro, visto que Estado e religião estiveram sempre unidos em Roma, quer tenha ou não a segunda sido criada para o fortalecimento do primeiro, como pensa Montesquieu. Entre os deuses e os homens, os porta-vozes dos primeiros na terra, com todas as conseqüências desse poder religioso. Excetuando-se as sortes, que são um dos mais antigos processos de adivinhação e mediante as quais tantos cônsules se elegeram (mais ou menos honestamente), as demais formas, sempre (ao meu ver) subalternas, ou independem da religião ou, embora pudessem até depender de um deus (sic), são fortuitas (como os avisos, os sonhos e o delírio), ou são estrangeiras (como a aruspicina) e/ou tardias (como a astrologia), ou dizem respeito mais a anseios individuais de ordem vária que ao serviço da República - ao passo que a arte augural é o grande poder do Estado.

É preciso, no entanto, considerar, primeiro, o domínio da tradição. Esta soube sempre exercer o seu poder e se, no que concerne às crenças, aos poucos até certo ponto se apaga, Augusto, logo após o período de Cícero, naturalmente contando com o auxilio da arte virgiliana, se preocupa em reacendê-la, ao ponto de levar mesmo longe demais o valor da adivinhação. Ora, a massa crê e os governantes e os intelectuais ou crêem ou the usam a crença. Assim, a história dos primeiros tempos, até onde se alcança, é plena de exemplos que se pretendem indiscutíveis de avisos divinos interpretados pelos áugures.

Também é preciso considerar até que ponto se confundem religião e superstição no último século da República. Se os deuses não são apenas invenções do Estado para obrigar o homem a respeitar a lei, ou se já não o são, visto que no século I invadem Roma deuses e cultos, religiões místicas e crenças de além-mar, na verdade, porém, a religião é ainda poderosa arma nas mãos dos poderosos. Como o periodo se caracteriza pelo individualismo, pela ambição e pela ânsia de poder, todas as armas são válidas: o engano e a mentira, a religião e a superstição. Ora, por mais que o negue Cícero, o romano de seu tempo é naturalmente supersticioso. Refiro principalmente o povo ignaro. Mas quem pode garantir que não o fossem, também, muitos dos homens cultos? $\mathrm{Ou}$ Tito Lucrécio Caro não sentiria tamanha aflição, como parece que sentiu, ao combater nos seus contemporâneos o comportamento absurdo que deriva de crenças absurdas, $\mathrm{e}$ no combater também as próprias crenças.

A verdade, porém, é que o homem se sente fraco e imagina, além e acima dele, forças que o protejam; tendência que, ao contrário do epicurismo, o estoicismo reforça, afirmando que os deuses dominam o mundo. E, se ambos os sistemas exercem influência em Roma, o estoicismo, filosofia que aí tem o seu mais fértil campo, traz no seu 
âmago justamente o conhecimento do futuro, a adivinhação. E o oscilante Cícero, que tão veementemente a critica, defende-a. Como bem assinala o poeta filósofo epicurista Lucrécio, o homem tende naturalmente para a superstição e, por mais que se lhe ensine a verdadeira natureza dos deuses e o verdadeiro sentido da piedade, volta sempre às antigas crenças $(\mathrm{V}, 82-90)$.

Materialista e coerente, Lucrécio clama contra todo tipo de superstição, a que chama religio e que distingue de pietas. Identifica à religio o medo aos deuses, os sacrificios sangrentos e as ameaças dos profetas e adivinhos, a quem é preciso resistir - minis obsistere uatum (I, 109) - e aos quais já antes chamara Ênio "supersticiosos e impudentes, ou sem arte e insanos": superstitiosi uates impudentesque harioli, aut inertes aut insani (Tel., fr.1-2).

O valor maior para o epicurismo é o bom-senso, a phróneesis de Epicuro, e o De rerum natura é o poema da razão. O Poeta chora pelo crime de Áulis (I, 80-101); a morte de Ifigênia não é para ele o cumprimento de um desejo divino e Calcas não é o intérprete de um deus: o holocausto da virgem não passa de uma brutalidade gerada pela ignorância. Chora pelo vitelo imolado no altar do sacrificio (II, 352-66), pelas nigrae pecudes oferecidas às almas infernais (III, 52): por todo lado, violência religiosa. Ora, tudo isso é o oposto da piedade. E o Poeta não quer uma religião a serviço de quem ou do que quer que seja: mas quer a piedade, que traz a paz.

Amante da natureza, amante da vida e dos seres vivos, Lucrécio vê a superstição como antinatural por excelência, fruto da ignorância sedenta de sangue, geradora de crimes. Quer a derrubada dos mitos. Os deuses no epicurismo não têm o menor compromisso com a humanidade: não tomam conhecimento dela e não lhe mandam recados. Assim, adivinhação e epicurismo são absolutamente incompativeis.

$\mathrm{O}$ autor de De rerum natura pretende, como seu mestre, uma cidade de sábios, na qual não se imponham nem a religião como freio, nem o medo mantenedor da ordem, como forma de domínio. E não transige: quer uma religião que liberte o homem, quer a identificação deste à terra, de onde vem e para onde volta, e o respeito à natureza e a todas as outras espécies vivas.

Parece-me interessante assinalar que Polibio, que nasceu aproximadamente setenta anos após a morte de Epicuro, conhecia, ao escrever as suas Histórias, não apenas o estoicismo, praticado no círculo dos Cipiões, que ele freqüentava, mas também a filosofia do Jardim, cidade epicurista de sábios, onde reinam o respeito, a amizade, a liberdade. Ora, a liberdade, bem pelo qual todos ansiamos, implica no homem responsabilidade, que, por sua vez, implica um mínimo de sabedoria. A massa inculta é, por isso mesmo, instável e irresponsável, segundo o historiador, que, apoiando-se em Platão, em Aristóteles e na sua própria experiência, estuda as diferentes formas de governo e vê os perigos que se escondem em cada uma dessas formas. Políbio vê, como Critias, o papel dos deuses mas aceita como necessário o freio defendido por Cícero e imposto à massa pela República, porque o homem não sabe ser livre. "Se se pudesse criar uma cidade de sábios", disse Políbio: mas sabe que não se pode. 
Marco Túlio Cícero não é historiador, não é filósofo, não é poeta (em que pesem os poemas que escreveu): é político. A $V r b s$ tem o seu amor. Se se dedica à filosofia, é à procura de solução para a estabilidade e a grandeza da República. Se defende a religião é porque esta lhe parece o único poder capaz de sustentar a um tempo o indivíduo e a coletividade. Se defende a religião oficial, é porque só esta pode manter o homem livremente submisso ao Estado. Se condena os deuses estrangeiros e defende a religião dos antepassados é porque sabe que a religião tem que ser una para ser estável.

Aliás, o Orador, para si quer a verdade. Talvez quisesse crer nalguma religião ou talvez apenas oscilasse entre crenças diferentes. Ou os seus diálogos, pondo face a face adeptos de filosofias opostas e expressando assim opiniões várias, talvez mostrem apenas que não crê mas, reservando-se o direito à dúvida (De diu., II, 12, 28), sente necessidade de fazer crer: a $V r b s$ precisa de um povo que creia.

O problema é que Cícero parece, como Lucrécio, em que pesem diferenças substanciais, querer ao mesmo tempo salvar a religião e abolir a superstição. Esforço inútil. Faz tempo que o Senado ostenta gravadas na pedra as palavras SENATVS POPVLVSQVE ROMANVS; mas no século I, enfraquecido, é o Senado vítima de facções que lutam para si mesmas: e o povo, de fato (embora tenham sido restabelecidos ao fim da década de 70 os seus tribunos, antes suprimidos por Sula), é vitima dos demagogos dos grandes ambiciosos que trabalham e lutam violentamente pela satisfação dos seus interesses pessoais. A incerteza dos tempos leva a uma ânsia aflitiva de saber o que reserva o amanhã, e já não bastam os antigos modos de consulta: os charlatães orientais aí estão com novos enganos e novas seduções mágicas, nos quais, lamentavelmente, acreditam os homens.

\section{Notas}

1- Cf. Suetônio, D. Iul., 59.

2- O cônsul de 95. A sua tese a respeito dos deuses encontra-se em Santo Agostinho (De ciu. Dei., 4, 27).

3- Discordam os estudiosos quanto à data de composição de De legibus. Por exemplo, para Bayet (1971, p. 284), 54; para De Plinval (1968, p. viii), 52.

4- Veja Ernout e Meillet, 1967, p. 586, col. 1

5- Cf. Bayet, s.d., p. 101; 1971, p. 300.

6- Cf. De leg., II, 12, 30.

7-Cf. Grimal, 1974, p. 134.

8- Cf. Ernout e Meillet, 1967, p. 56, col. 2.

9- Veja Dumézil, 1969, p. 100.

10- Veja De leg., II, 12, 31.

11- Cf. Bayet, 1971, p. 278 seq.

12- Veja De leg., III, 12, 27.

13-Demosthenes quidem [...] iam tum philippizein Pythiam dicebat (De diu., II, 57, 118).

14- Veja Schilling, 1979, p. 192 seq. 
15- Veja Boyancé, 1963, p. 95 seq.

16- Veja, p. ex., Antologia, 1988, p. 44-7.

17- Veja Bayet, 1971, p. 55 seq.

18- Veja Boyancé, 1963, p. 117.

19- Veja Petit, 1968, p. 100.

20-Veja Schilling, 1979, p. 190.

21- Cf. Ernout e Meillet, 1967, p. 289, col.2.

22- Veja Appuhn, 1937, n.266.

\section{Referências Bibliográficas}

ANTOLOGIA BILINGÜE.DE ESCRITORES LATINOS, I. História. São Paulo: DLCVFFLCH-USP, 1988.

APPUHN,C. Cicéron. De la divination, Du destin, Académiques. Paris: Garnier, 1937.

BAYET, J. Croyances et rites dans la Rome antique. Paris: Payot, 1971.

BAYET, J. La religion romaine. Histoire politique et psychologique. Paris: Payot, s.d.

BLOCH, R. Tite Live et les premiers siècles de Rome. Paris: Les Belles Lettres, 1965.

BOYANCÉ, P. La religion de Virgile. Paris: PUF, 1963.

CICERO. De diuinatione. London: W.Heinemann - Cambridge, Mass.: Harvard, 1953.

CICÉRON. De la divination. Paris: Gamier, 1937.

CICÉRON. De la nature des dieux. Paris: Garnier, 1935.

CICÉRON. Traité des lois. Paris: Les Belles Lettres, 1968.

CICERONIS, M. T. Scripta quae mansuerunt omnia, Fasc.45 De natura deorum. Stuttgart: Teubner, 1968.

COULANGES, F. de. La cité antique. Paris: Hachette, 1969.

DE PLINVAL, G. Cicéron. Traité des lois. Paris: Les Belles Lettres, 1968.

DUMÉZIL, G. Idées romaines. Paris: Gallimard, 1969.

DUMÉZIL, G. La religion romaine archaique. Paris: Payot, 1974.

ERNOUT, A. e MEILLET, A. Dictionnaire étymologique de la langue latine. Paris: C.Klincksieck, 1967.

GRIMAL, P. La civilisation romaine. Paris: Arthaud, 1974.

LUCRĖCE. De la nature. Paris: Les Belles Lettres, 1978/1975. 2v.

MADAULE, J. César. Paris: Du Seuil, 1961.

MONTESQUIEU, C. de S., Baron de. De la grandeur des romains et de leur décadence. Paris:

Garnier, s.d.

PETIT, P. La civilisation hellénistique. Paris: PUF, 1968.

POLYBE. Histoires, Livre VI. Paris: Les Belles Lettres, 1977.

SCHILING, R. Rites, cultes, dieux de Rome. Paris: C.Klincksieck, 1979.

VIRGILE. Énéide. Paris: Les Belles Lettres, 1966/1967. 2v. 
NOVAK, M. G. Divination, superstition et religion au dernier siècle de la République (Cicéron et Lucrèce). Clássica, São Paulo, 4: 145-161, 1991.

RÉSUMÉ: La religion et la superstition se confondent au dernier siècle de la République et la religion est une arme puissante aux mains des plus puissants. L'homme se sent faible et il imagine des forces surnaturelles qui le protègent ce qui est renforcé par l'estoïcisme et combattu par l'épicurisme. Par suite, la divination et l'épicurisme sont tout à fait incompatibles. Lucrèce s'écrie contre la superstition et la folle conduite qui en résulte. Cicéron, qui critique la divination, quand-même la défend et défend tout aussi bien la religion officielle car il sait bien qu'il n'y a que celle-ci qui puisse maintenir l'homme librement soumis à l'État.

MOTS CLÉs: Divination romaine, Cicéron, Lucrèce. 